\title{
Introduced brown algae in the North East Atlantic, with particular respect to Undaria pinnatifida (Harvey) Suringar
}

\author{
R. L. Fletcher \& P. Farrell \\ Institute of Marine Sciences, University of Portsmouth, Ferry Rd, Eastney, \\ Portsmouth PO4 9LY, UK
}

\begin{abstract}
The recent introduction of the macroalga Undaria pinnatifida (Harvey) Suringar into the North Atlantic is the latest of a large number of introductions, which have occurred over many years. Some have been deliberate introductions for mariculture or research, while most have been accidental, via vectors such as shipping and shellfish imports. Not all newly recorded species are introductions; some are thought to be merely extensions of distribution, e.g. Laminaria ochroleuca, while others may have been overlooked previously, e.g. Scytosiphon dotyi. Subsequent to its accidental introduction into the waters around the Mediterranean French coast at Sete, most likely with imported oysters, Undaria was deliberately introduced into the North Atlantic, to Brittany, in 1983 by IFREMER for commercial exploitation. Undaria has since spread from the original sites in Brittany, and is now established at several sites on the south coast of England. This paper discusses the introduced brown algae in the North Atlantic and outlines the establishment of Undaria in the UK.
\end{abstract}

\section{INTRODUCTION}

The introduction of marine species into new, distant coastal regions as a result, directly or indirectly, of human activity is now commonplace and there are few regions in the world which remain unaffected. The North East Atlantic, in particular, has been the focal point of a large number of introductions and this is reflected in a growing volume of scientific literature on the subject (see Farnham, 1980, 1994, 1997; Rueness, 1989; Boalch, 1994; Boudouresque, 1994; Eno et al., 1997). Whilst some introductions are deliberate, for experimental purposes or for mariculture practices, most are accidental and the result of "hitching a ride" on a wide range of vectors. The latter include the hulls of ships, ballast water and imported shellfish and their "transportation" role finds support in the relatively large number of introductions which are initially associated with harbours and/or shellfish cultivation areas.

\section{HISTORY OF BROWN ALGAL INTRODUCTIONS IN THE NORTH EAST ATLANTIC}

With respect to algal introductions into the North East Atlantic, most attention has been given to the macroalgae (Farnham, 1980, 1994, 1997; Eno et al., 1997) with few re(c) Biologische Anstalt Helgoland, Hamburg 
Table 1. Brown algae introduced into the North Atlantic, with details of most probable arrival dates, vectors and places of origin

\begin{tabular}{|lcll|}
\hline Alga & Arrival date & \multicolumn{1}{c|}{ Vector } & Origin \\
\hline Colpomenia peregrina & 1905 & Imported oysters & North Atlantic \\
Fucus evanescens & 1924 & Unknown & Pacific \\
Laminaria longicruris & $1970 \mathrm{~s}$ & Scientific research & North Atlantic \\
Laminaria ochotensis & $1970 \mathrm{~s}$ & Scientific research & Pacific \\
Macrocystis pyrifera & 1973 & Commercial trials & Pacific \\
Sargassum muticum & $1960 \mathrm{~s}$ & Oysters & Pacific \\
Undaria pinnatifida & 1984 & Commercial trials & Pacific \\
Corynophlaea umbellata & 1986 & Sargassum muticum & Pacific \\
\hline
\end{tabular}

ports pertaining to the more microscopic diatom group (Boalch, 1994; Eno et al., 1997). Table 1 lists the marine brown algae which are known, or are considered, to have been introduced to date into the North East Atlantic region. Not included are brown algae which are known to have increased their local distribution in the North East Atlantic. For example, Laminaria ochroleuca, a warm temperate kelp, appears to have extended its northerly distribution into the English Channel and was first reported for the British Isles in 1948 by Parke (Parke, 1948). Similarly, Zanardinia prototypus was first reported on the south coast of England in 1975 by Jephson et al. (Jephson et al., 1975) having previously only been known as far north as the Channel Islands, whilst Pseudolithoderma roscoffensis, newly reported for the British Isles in 1973 (Fletcher, 1987), was only previously known from Brittany.

These apparently recent cross-channel migrations might perhaps be the result of temperature increases in the North Atlantic, as suggested for Laminaria ochroleuca (Farnham, 1980). However, in the case of $P$. roscoffensis, because of its procumbent habit and fairly restricted distribution, it may just have been overlooked. Certainly there are numerous examples of species expanding their distribution in the North Atlantic because their small size and/or taxonomic difficulties prevented their initial identification [for example, the first report of Streblonema oligosporum for the British Isles (Fletcher, 1983)]. These have also been omitted from Table 1. Also excluded is Scytosiphon dotyi, a Pacific species first reported by Fletcher (1974) (see also Fletcher, 1987) for the European coast, at two localities in the British Isles, and subsequently for Trieste, Italy, by Giaccone (1978). It is likely, certainly in the case of the British Isles material, that this species does not represent an introduction but has merely been overlooked.

Probably the best known and most genuine, early brown algal immigrant into the North Atlantic is the oyster thief, Colpomenia peregrina, which was first reported in northern France at the beginning of this century, arriving in southern England in 1907 (Cotton, 1908). It is likely that this species was introduced from the Atlantic coast of North America with juvenile American oysters Crassostrea virginica (Farnham, 1980; Eno et al., 1997). Since its introduction, the species has widely extended its geographical range, from Iberia to southern Norway (Eno et al., 1997). Another likely early immi- 
grant is Fucus evanescens, first reported for southern Norway in 1924 and considered to have been introduced from the Pacific about 100 years ago (Bokn \& Lein, 1978; Schueller \& Peters 1994; Ribera \& Boudouresque, 1995). It is possible, however, that there are other more earlier examples of introduced brown algae, probably as a result of ship movements over the centuries, but which were undetected at the time of arrival and are now accepted components of the North Atlantic flora.

It was not then until the early 1970s that other brown algae were introduced into the North Atlantic. These comprised one fucoid, Sargassum muticum, the Canadian kelp, Laminaria longicruris, the Pacific kelp, Laminaria ochotensis and the giant Pacific kelp, Macrocystis pyrifera. With the exception of S. muticum, which was an accidental introduction, the kelps were deliberately transplanted. The two laminarians were introduced in cross-fertilisation experiments with European species at Helgoland in the North Sea (Boiton et al., 1983) whilst the Macrocystis was introduced into the Roscoff area, northern France in 1972 using sporophylls derived from Chile as part of a commercial trial. All the above trials and experiments were terminated before the plants became fertile. However, the experiments with Macrocystis caused particular concern (Franklin, 1974; Boalch, 1981), especially in view of proposals to carry out large-scale experiments which would allow the plants to become fertile. Much concern was expressed about the ecological impact the introduction would have on existing marine ecosystems. As a result of pressure from the International Council for the Exploitation of the Sea (ICES) the French biologists agreed to end the project (Franklin, 1974). As a consequence of these decisions to terminate the experimental trials none of the above kelps became established in the wild.

Particularly well documented was the accidental introduction of Sargassum muticum into the North Atlantic. First observed on the south coast of England in 1973 by Farnham et al. (1973), this population was most likely derived from an earlier introduced population on the French coast (Verlaque, 1994). Whilst the French population was unintentionally introduced with commercial introductions of oysters from British Columbia or Japan, its spread to the south coast of England was probably the result of the "remote" dispersal mechanism of drifting, fertile laterals. This mechanism of dissemination has subsequently been responsible for widely distributing $S$. muticum in the North Atlantic and its current distribution extends from southern Norway to Portugal (Rueness, 1989). The introduction of S. muticum into the Mediterranean was probably similarly aided by oyster importations from the Pacific and it was first reported in the oyster growing region of Sete in 1983 (Knoeffler-Peguy et al., 1985). Interestingly, Sete has also been the focus of other brown algal invasions into the Mediterranean e.g. the Pacific kelp Laminaria japonica (Boudouresque et al., 1985), Desmarestia viridis, Chorda filum and Sphaeotrichia divaricata (Riouall, 1985). Sargassum has considerably extended its distribution in the Mediterranean, mainly in an easterly direction along the French coast, probably due to the dissemination of drift material. The report of S. muticum in the Venice lagoon by Gaetano (1992), however, was probably the result of oyster importations.

One interesting aspect of the introduction of $S$. muticum relates to the discovery of a small brown epiphyte on its thalli which has been provisionally identified as Corynophlaea umbellata (C. Agardh) Kutz. (R.L. Fletcher, unpublished). This species, 
which is newly reported for the North Atlantic, has been found epiphytic on the thalli and air bladders of $S$. muticum plants growing in Langstone Harbour, south coast of England. Whilst this species is widely distributed in the Mediterranean as an epiphyte on fucoid algae such as Sargassum and Cystoseira spp. (Ribera et al., 1992), it is considered more likely that it was introduced from the Pacific along with $S$. muticum rather than from the Mediterranean. Certainly it is known as an epiphyte on $S$. muticum in Japan (Tokida, 1954). Pertinent to this discussion is the possible role played by S. muticum in the transportation of the cosmopolitan invertebrates Janua (Dexiospira) brasiliensis (Grube) and Pileolaria (Pileolaria) rosepigmentata Uchida. Both these species were newly reported for the North Atlantic during the early 1970s (KnightJones et al., 1975; Thorp et al., 1986; Eno et al., 1997). Whilst it is more likely that they were originally introduced into the North Atlantic by international shipping (Critchley \& Thorp, 1985; Zibrowius \& Thorp, 1989), it is possible that they were introduced with S. muticum (Critchley et al., 1990; Eno et al., 1997). Certainly there is strong evidence that drifting fragments of $S$. muticum were the most likely agency for the introduction of the former species into Dutch waters from other European localities (Critchley \& Thorp, 1985; Eno et al., 1997).

Finally, it can be seen in Table 1 that approximately 20 years on from the discovery of $S$. muticum, another large brown alga, Undaria pinnatifida (Harvey) Suringar, has been introduced into the North Atlantic. The introduction and impact of this alga will be the subject of the remaining part of this small review on introduced brown algae.

\section{ARRIVAL AND SPREAD OF UNDARIA PINNATIFIDA IN THE NORTH ATLANTIC}

Subsequent to its accidental introduction into the Mediterranean French coastal waters at Sete, most likely with imported oysters, the large kelp Undaria pinnatifida was deliberately introduced into the North Atlantic, to Brittany, in 1983 by IFREMER for commercial exploitation (Perez et al., 1984; Perez-Cicera et al. 1991; Castric-Fey et al., 1993). It was initially cultivated at three sites: the island of Groix in the south, the island of Ushant in the Bay of Lampaul to the west near Brest, and in the La Rance estuary near St. Malo. Later, additional experimental trials were performed under the auspices of CEVA at a number of Brittany sites: the island of Quessant, La Rance estuary, Abers, Trieux, Pleubian, Guilvinec, Oleron and the Chausey Islands. However, the anticipated market for the alga was not realised for a number of reasons (Ribera and Boudouresque, 1995) and many, if not most, of these farms have now been abandoned.

Not surprisingly, with all this mariculture activity, the first wild populations of $U_{n}$ daria were discovered close to the experimental culture sites. In 1987, wild populations of Undaria were found close to the seaweed farm on the island of Quessant (Floc'h et al., 1991, 1996; see Fig. 1).

Settlements have also been observed at two sites close to St Malo in 1992, confirming an earlier sighting of this alga in 1986, as well as at a number of additional sites on the Brittany coast all in close proximity to seaweed farms, i.e. Groix, Quessant, Aber Wrac'h, Brest, Lazardrieux, St. Malo and Granville (Floc'h et al., 1996; see Fig. 1). However, the rate of initial spread of the Undaria plants into the wild and the population 


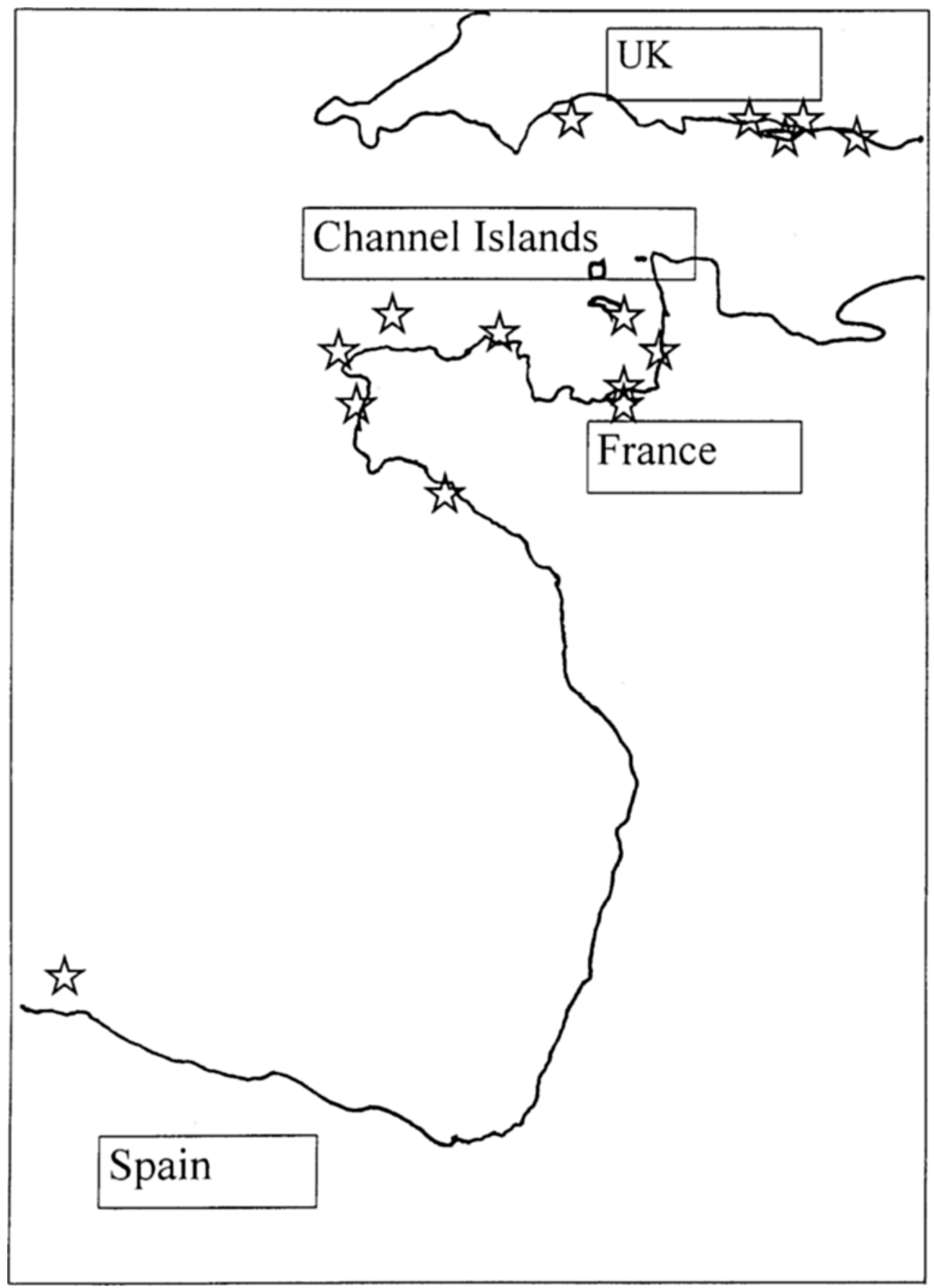

Fig. 1. The approximate position of introductions of Undaria into the North East Atlantic, indicated by star symbols 


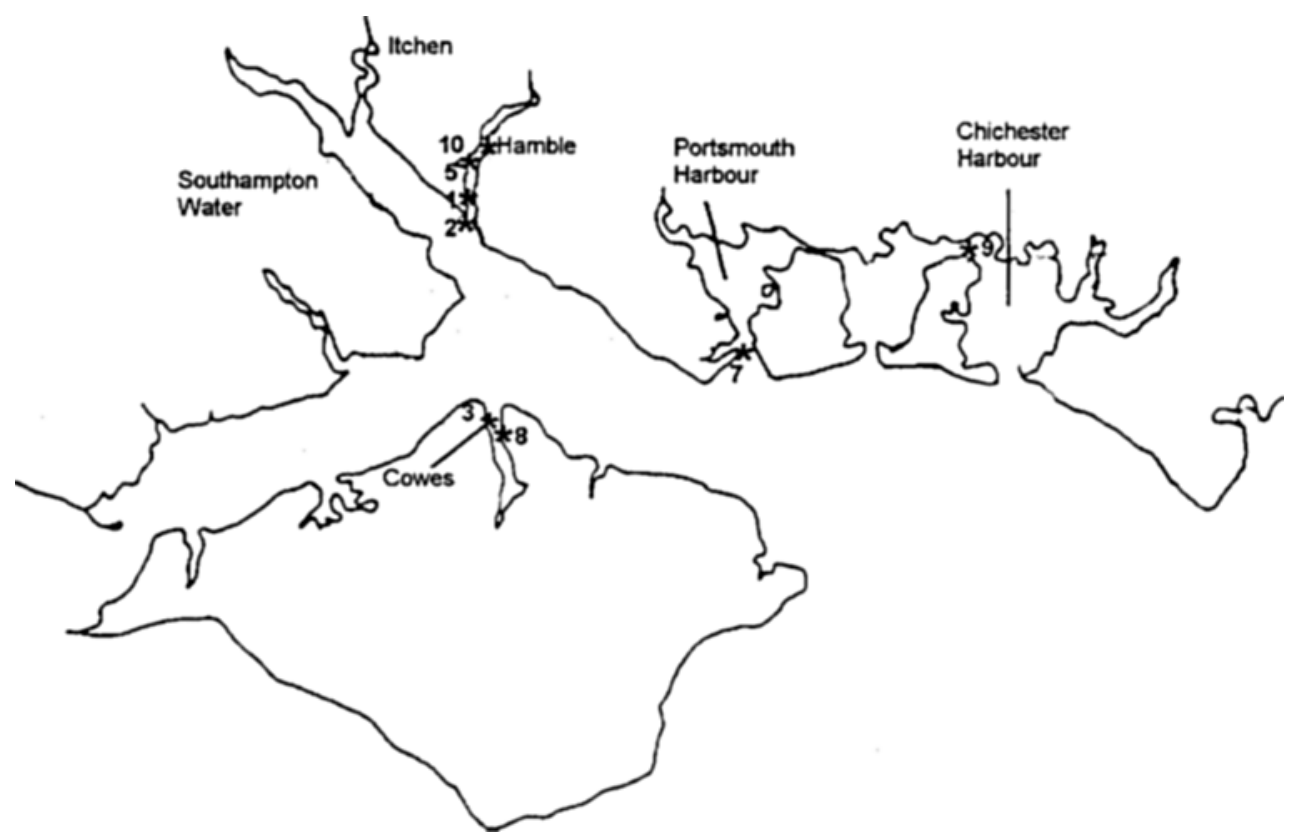

Fig. 2. Locations in the Solent (south coast of England) where Unclaria has been discovered. Numbers are in chronological order of introduction. 4 and 6 are outside of the Solent, and are mentioned in the following key: 1 Port Hamble Marina, Hamble Estuary, June 1994; 2 Hamble Point Marina, Hamble Estuary, March 1996; 3 West Cowes Marina, Isle of Wight, August 1996; 4 Torquay Marina, Devon, June 1996; 5 Mercury Yacht Harbour, Hamble Estuary, March 1997; 6 Brighton Marina, Sussex, June 1997; 7 Haslar Marina, Portsmouth Harbour, December 1997; 8 East Cowes Marind, Isle of Wight, April 1998; 9 Northney Marind, Chichester Harbour, April 1998 (boat), July 1998 (pontoons); 10 Swanwick Marind, Hamble Estuary, June 1998

build-up has been slow. For example, Castric-Fey et al. (1996) report that after its first appearance in 1986 and then later in 1987 and 1988, it appeared to be "discrete" during 1989, 1990 and 1991. This was then followed by a population explosion. In experimental studies by Floc'h et al. (1996), rocky subtidal areas seeded with Undaria spores showed little or no recruitment of sporophytes. They also observed that recruitment decreased dramatically with distance from a nearby farm. They concluded that the species was moving stepwise from the farm into the wild.

Despite the apparent absence of an inherent long range dispersal mechanism, three more distant populations of Undaria have been reported for the North Atlantic region (see Fig. 1). These are at Galicia, in northern Spain (Santiago Caamano et al., 1990), on Jersey in the Channel Islands (Fletcher \& Farrell, unpubl.) (see below) and on the south coast of England (Fletcher \& Manfredi, 1995). In these instances, human activity was probably responsible. It is likely that the plants in Spain were introduced through oyster transfers (Curiel et al., 1994; Floc'h et al., 1996). The plants in Jersey and England, however, most probably came from Brittany attached to small boats, as the initial sites of infection were the floating pontoons of marinas. On the south coast of England, for 


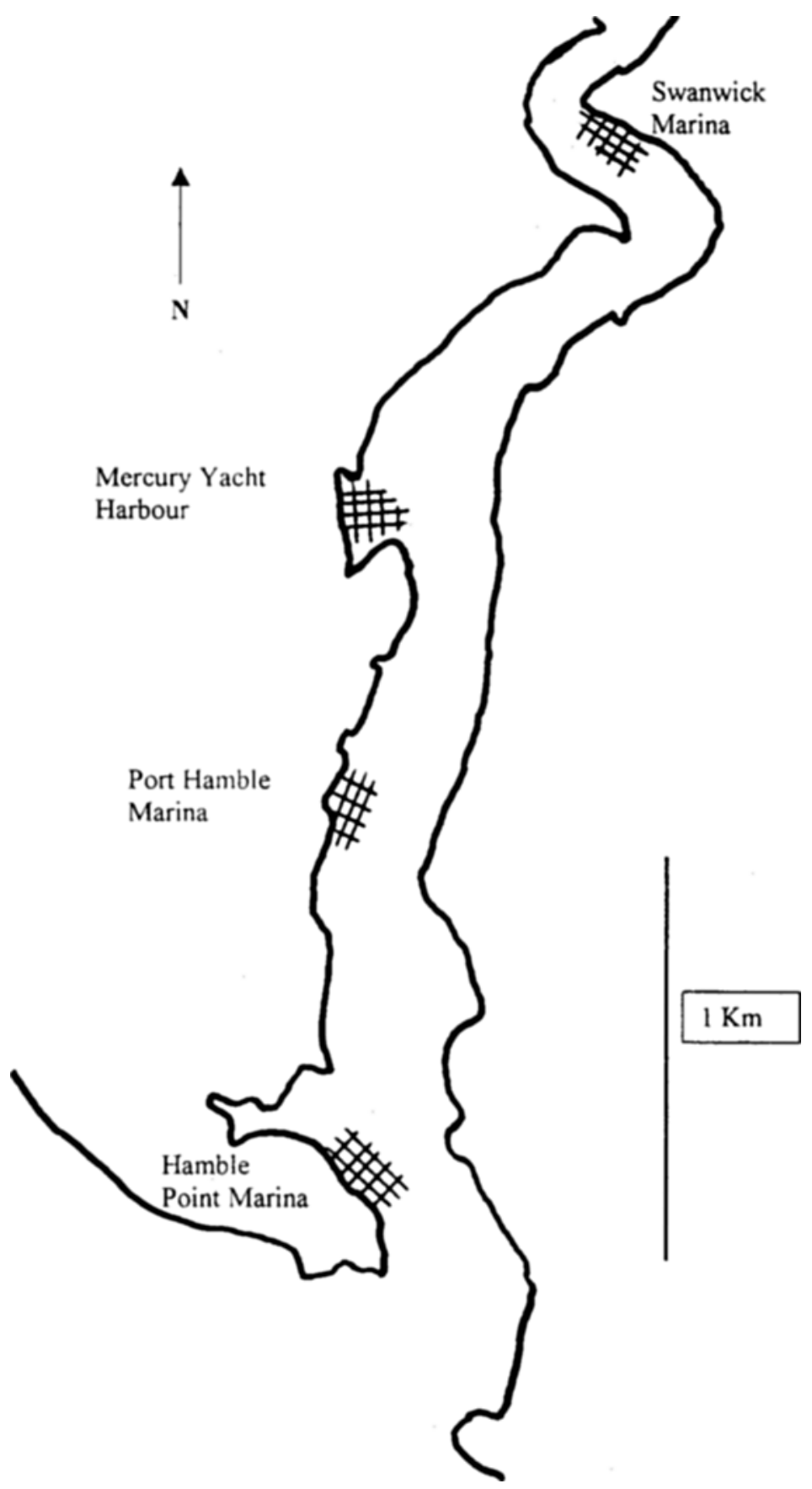

Fig. 3. The main marinas in the Hamble Estuary referred to in the text 
example, plants were first discovered at Port Hamble Marina in the Hamble Estuary, Southampton Water (see Figs. 2 and 3). This marina is one of four large marinas in the Hamble Estuary, and there are over 25 similar marinas in this mid-south coast region alone. Also, in the Hamble Estuary, there are 1201 permanent moorings for Hamblebased leisure craft, and the estuary receives over 14000 visiting boats per year. It is also noteworthy that more than $50 \%$ of departures of Hamble-based boats leave direct for France. With such a large volume of cross-channel traffic, it is most probable that a boat introduced Undaria into the Solent region, either in the form of gametophytes or small sporophytes. Certainly there is evidence that both these stages can survive long journeys on the hulls of boats (Hay, 1990). Support for boats as the most likely vector for the introduction of Undaria into the British Isles is also provided by the occasional observation of plants on the hulls of leisure craft moored at the marinas. With the alga's known preference for artificial substrata, and especially floating structures such as buoys, floats, landing stages, etc. (see below for references), it seems most probable that a small boat became infected with Undaria at one of the many ports and marinas on the Brittany coast.

After the initial discovery of the south coast of England population, all the plants were removed. However, this attempt at eradication proved futile as some of the plants were already fertile and further plants were subsequently discovered at the marina. Indeed, Undaria has now considerably extended its distribution, both in the Hamble Estuary and along the south coast of England.

Figure 2 presents a chronology of the localities on the south coast of England where Undaria has been observed to date. Most of the new sightings were the result of a monitoring programme of marinas on the south coast of England; the discovery of Undaria at Torquay Marina and Cowes Marina, however, was in response to a circular distributed extensively to marina managers, harbour masters, port authorities, etc.

Whilst it is most likely that the majority of these new infestations are due to intermarina traffic on the south coast of England, some undoubtedly represent independent transfers from the Brittany coast. This certainly seems to be the case with respect to the 25-ft Fisher ketch Antares, which was probably responsible for introducing Undaria into Northney Marina. Plants were first observed attached to the hull in April 1998, and then later, in July 1998, they were observed attached to adjacent floating pontoons (L. Haggerty, pers. comm.). Prior to being moored at Northney Marina at the end of August 1997, where she has since stayed, Antares spent the preceding 3 weeks visiting the Brittany coast, with the following itinerary: Cherbourg Marina, St. Helier Marina (Jersey), St. Malo Marina, up the La Rance estuary, La Collette Marina, La Place Marina, back to St. Malo Marina, Grandville Marina, St. Helier Marina, Cherbourg Marina and then straight back to Northney Marina. Before she sailed south, her hull was cleaned at Northney Marina. It is likely that Undaria was introduced onto the hull during her stay at one of the Brittany marinas. Although Undaria is present in St. Helier Harbour, Jersey, the relatively small population is at La Collette Yacht Basin and was not found at St. Helier Marina during a recent visit (July 1998). This makes it unlikely that Undaria was introduced onto the hull during Antare's stay in Jersey.

It is apparent from Fig. 2 that all new sightings of Undaria on the south coast are quite well isolated geographically and are all at marinas. Clearly, small leisure boats are 
playing a major role in the "assisted" spread of Undaria along the south coast, as reported by Hay (1990) for Wellington Harbour, New Zealand. Certainly some examples were found of boats, colonised by Undaria, moving from one marina site to another. For example, the sailing sloop Coralendo which was moored at Port Hamble Marina from March 1997 to May 1998 was moved directly to Hythe Marina, situated further up on the other side of Southampton Water, where she remained for 4 days prior to being cleaned. During the cleaning process she was observed to have a large fertile Undaria plant attached to the hull. There is, therefore, a very good chance that Undaria has now been introduced into Hythe Marina. It is by this mechanism that Undaria is likely to quite rapidly extend its geographical range both around the British Isles and along the European mainland coast. In this respect, its long-range passage is independent of current movements, which by contrast have played a major role in the dissemination of Sargassum muticum in European waters. Undaria now extends between Brighton and Torquay, a distance of approximately $270 \mathrm{~km}$ and it did this in a much shorter space of time than Sargassum.

In contrast to the above described "remote" dispersal of Undaria, local spread from the marinas has been less marked. Figure 2 indicates, for example, that it took nearly 3 years to reach Mercury Marina from Port Hamble, a distance of approximately $750 \mathrm{~m}$, and it took 4 years to reach Swanwick Marina, a distance of approximately $2 \mathrm{~km}$. This "upstream passage" of Undaria, especially to Swanwick Marina, may have been delayed by the reduced salinity of the water at these marinas and, perhaps, the eventual colonisation of their floats was determined by the availability of a certain environmental "window of opportunity". Note, however, that it also took nearly 2 years for Undaria to travel downstream to Hamble Point Marina, a distance of approximately $750 \mathrm{~m}$. Even the local spread of Undaria on the pontoons of each marina appears to be a stepwise procedure. For example, when first observed at Port Hamble Marina, in June 1994, the plants were distributed on the sides of nine pontoons (Fletcher \& Manfredi, 1995), in May 1996 they occupied the sides of 274 pontoons, and then in May 1997 they occupied the sides of 741 pontoons (1997 figures courtesy of J. Sharp and J. Lauder, personal communication). This figure for 1997 represents approximately $90 \%$ of the number of pontoons available for colonisation.

This relatively slow but progressive local colonisation of the pontoon floats, and adjacent marinas, seems surprising in view of the large number of plants present, the enormous reproductive spore potential of each plant and the reported motile periods of the spores of up to $5 \mathrm{~h}$ (Saito, 1975; Akijama \& Kurogi, 1982; Hay \& Luckens, 1987). Further, with such a large input of spores from the Hamble Marina into the tidal waters and currents of Southampton Water, it would also be expected that Undaria would be extensively distributed within the Solent region. This has not happened. For example, to date Undaria has not been observed anywhere along the length of Southampton Water except in the Hamble, despite the wide range of habitats and substrata, including artificial ones, available to it. It has not yet, for example, been observed in the slightly higher positioned Itchen Estuary, where the pontoons of the Ocean Village Marina and the Shamrock Marina would provide ideal substrata for it to colonise. Nor has it been observed, to date, on the other side of Southampton Water opposite the Itchen, at Hythe Marina. Clearly a large reproductive spore output is no guarantee of successful recruit- 
ment, and parallels can be drawn here with the above mentioned slow natural spread of Undaria from the cultivation sites in Brittany (Floc'h et al., 1996). Such a poor rate of sporophyte recruitment, despite huge zoospore outputs, seems to be characteristic of kelps and most probably relates to limitations imposed by the gametophyte life history stage. Other reports attributing Undaria with a slow rate of spread include those of Floc'h et al. (1991) who pointed out that it took 10 years for Undaria to escape into the open Mediterranean Sea from the relatively enclosed Etang de Thau lagoon, Hay's (1990) report of the relatively slow spread by tidal currents (16 miles over a probable period of 5 years) of Undaria along the coastline in Mercury Passage, Tasmania, his report of the relatively late discovery of Undaria in 1989 outside Timaru Harbour, New Zealand, despite evidence that it had been introduced several years earlier in the early 1980s, and his report of the slow "natural" spread of Undaria in Wellington Harbour, New Zealand, over the years 1987, 1988 and 1989.

\section{ECOLOGY OF UNDARIA ON THE SOUTH COAST OF ENGLAND}

On the south coast of England, Undaria is very largely restricted at present to the vertical sides of floating structures. These include mainly the floating pontoons of marinas, and to a lesser extent floating wharves and the hulls of small boats, although plants have also been observed growing on a wide variety of structures attached to, or suspended from the floating pontoons, including ropes, buoys and tyres. A similar tendency for plants to colonise floating structures, at or just below the water line, has been reported by Hay (1990) for Undaria in Wellington Harbour, New Zealand, by Floc'h et al. $(1991,1996)$ and Castric-Fey et al. (1993) for Undaria in Brittany, and by Brown and Lamare (1994) for Undaria in Timara Harbour, New Zealand.

Despite Undaria's widespread distribution and abundance on floating structures in the Hamble Estuary, it has only rarely been observed attached to any of the numerous fixed structures (e.g. wood and concrete pilings, piers, harbour walls) which are present. Even Styela clava, a very common host when occurring on floating structures, is very rarely found with attached Undaria when growing on fixed structures. This does seem surprising in view of numerous world wide reports highlighting Undaria's frequent tendency to colonise fixed artificial structures (Hay, 1990; Brown \& Lamare, 1994; Casas \& Piriz, 1996; Floc'h et al., 1996). Apart from scattered isolated plants found on the pilings, the only other non-floating population of Undaria observed in the Hamble comprises a number of small plants first seen on 1 June 1996 at LWST on a shingle spit at the Hamble entrance, a short distance from the Hamble Point Marina. This general absence of plants on the fixed structures is probably due to a combination of the high sediment loading and high turbidity of the estuarine waters, restricting light penetration and preventing spore attachment and recruitment. Note that at Granville, Normandy, Undaria plants found growing in rather poor conditions and in muddy waters were very reduced in size (Floc'h et al., 1996) whilst similar observations were made about the size of plants growing in highly turbid waters of the Mediterranean (Floc'h et al., 1988).

In contrast, at Torquay Marina, the only other locality observed to date where Undaria has "escaped" from the floating pontoons, a much more rapid colonisation of lo- 


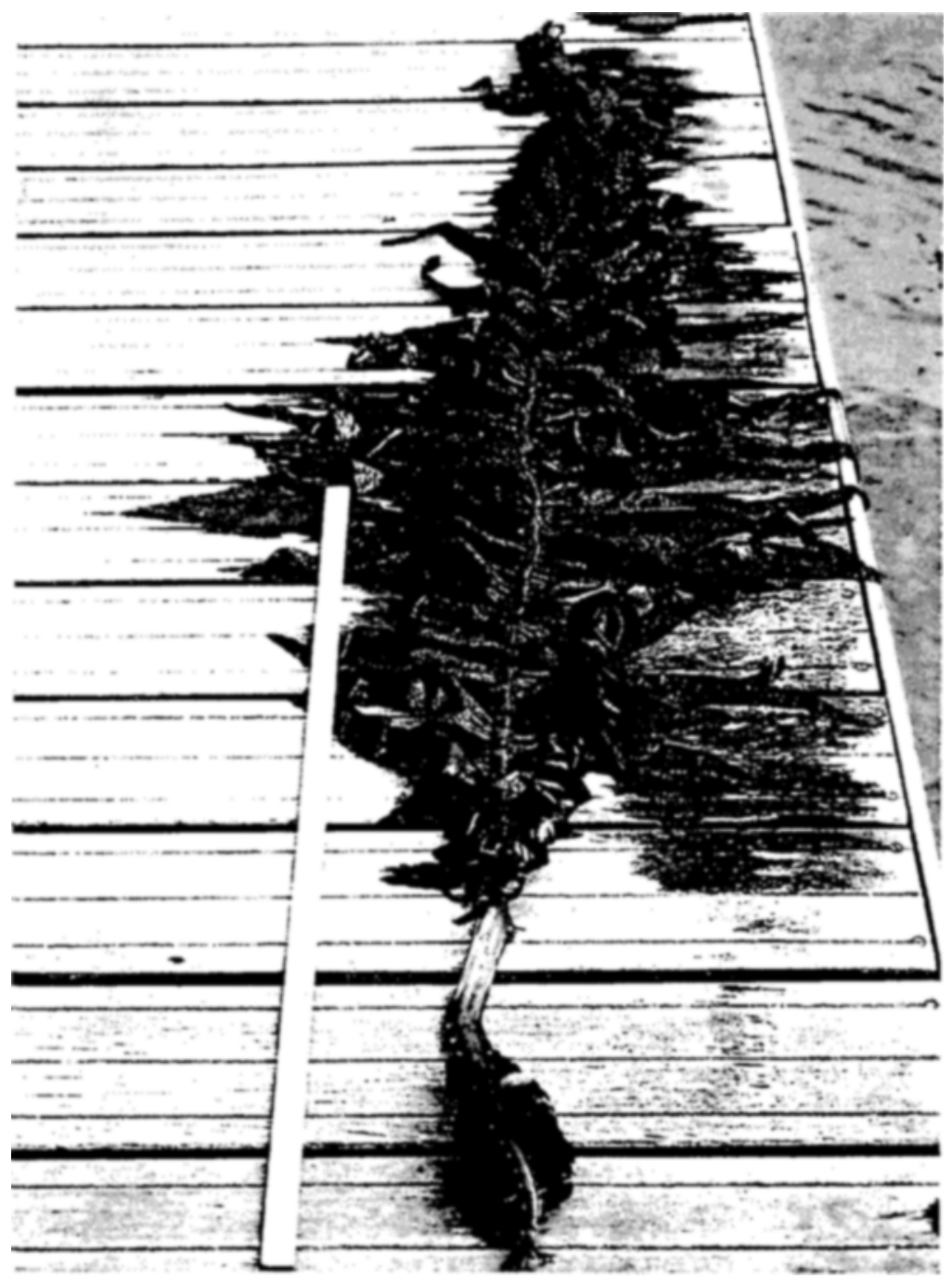

Fig. 4. Mature sporophyte collected from the Hamble Estuary (Solent, UK) in August 1997. The specimen measured $2.4 \mathrm{~m}$ and weighed $985 \mathrm{~g}$. (wet weight)

cal fixed structures has occurred. Within 1-2 years of colonising the floats, several plants were observed at LWST attached to the base of the marina walls, in association with the native kelps Laminaria digitata and Laminaria saccharina. This more rapid spread into the benthos most probably relates to the clearer, less turbid waters of this more exposed coastal harbour. It is likely that Undaria will be a major fouling alga in this harbour and very rapidly escape onto the surrounding open rocky coast. Interestingly, Saccorhiza polyschides is a common fouling alga on the outer harbour walls and occurs quite abun- 
dantly in the sublittoral fringe area of the adjacent rocky shore. In view of speculation about possible competition between Undaria pinnatifida and Saccorhiza polyschides in the North Atlantic (Hay, 1990; Castric-Fey et al., 1993; Fletcher \& Manfredi, 1995) the eventual cohabitation of these two species at Torquay is likely to provide an excellent opportunity for some experimental studies. With this in mind, some experiments were initiated in $1997^{\prime}$ and the results will be presented in a later communication.

At all the marinas studied, Undaria was the dominant fouling alga on the majority of pontoon floats, growing to a large size (see Fig. 4) and attaining biomass levels of up to $25 \mathrm{~kg}$ wet weight per $\mathrm{m}^{2}$. In the Hamble, for example, the only other large algae present were occasional scattered plants of Laminaria saccharina, Sargassum muticum and, just above the water line, Fucus spiralis. These plants also tended to colonise only the outer more wave-exposed (from passing boats) pontoons and those exposed to stronger tidal currents, whereas Undaria was found almost equally well distributed on the inner extremely sheltered pontoons and high sediment loaded pontoons lying adjacent to the marina walls. The other brown algae were also only found more downstream at the Port Hamble and Hamble Point Marinas and were absent from the more freshwater influenced Mercury and Swanwick Marinas. Clearly, Undaria is tolerant of a much wider range of environmental conditions than these algae and this ability to colonise sheltered substrata not covered by native species was also noted by Casas and Piriz (1996) in their study of an introduced Undaria population in Argentina. Outside the Hamble, only the outer positioned, more wave-washed floats of marinas supported reasonably well developed communities of large brown algae. Here Laminaria digitata was often well established, forming thick stands facing out across the harbours and exposed to frequent wave-wash. This was accompanied by occasional plants of Desmarestia viridis, Laminaria saccharina and, at Torquay only, Saccorhiza polyschides. These stands will provide severe competition for Undaria and it will have much more difficulty in colonising the pontoons unless "windows of opportunity" are provided, for example, if surfaces are stripped by winter storms or boat activities. Again, these areas provide excellent opportunities for competition studies.

\section{ESTABLISHMENT OF UNDARIA ON THE SOUTH COAST OF ENGLAND: EXPLANATIONS AND IMPLICATIONS}

Clearly, Undaria can now be considered as a permanent addition to the marine algal flora of the south coast of England and all the requirements for a successful invasion have been fulfilled. For example, the "means of transportation" was provided by the large number of small boats, both British and French, which regularly cross the Channel from Brittany to the harbours and marinas on the south coast of England. Very often these small boats are not adequately antifouled and their hulls provide ideal, non-toxic environments for the settlement and establishment of the reproductive spore stages. The slow passage of the majority of these boats will also allow these stages to remain securely attached to the hull during transit. Following transportation, it is then important that the introduced alga is provided with a period of consolidation in order to be- 
come established. The success of this establishment will, however, depend on the size of the initial invasion. For Undaria this requirement was probably met by the long "laying up" periods of the boats moored at the marinas on the south coast of England. The great majority of these cross-channel boats would probably visit the Brittany coast for only a few weeks during the summer and then return to spend the remainder of the year moored at their home marina. This would allow the attached gametophytes/sporophytes to continue development until large fertile plants were present on the sides of the hull. Zoospores released from these plants would then infect the adjacent marina pontoons. An additional important contributory factor to this required consolidation period was the likelihood that several "introductions" of Undaria plants, rather than one, occurred on the south coast of England, as evidenced by the travel details of Antares. There is the further likelihood that secondary invasions occurred as a result of intermarina traffic on the south coast of England. Both these primary and secondary invasions would have provided the required consolidation period.

Boats would also have provided the means of marginal spread (the "expansive phase" according to Ribera, 1995), an important requirement for the successful introduction of a species. By this means Undaria is likely to spread from the south coast of England all around the British Isles. However, Undaria also has the ability to spread naturally by the formation and release, throughout the year, of very large quantities of motile reproductive zoospores. It is likely that these will be distributed in the direction of the prevailing currents and this will determine the natural spread of the plants on the south coast of England. To date, however, this method of dispersal seems very slow, both on the south coast of England and in Brittany (Floc'h et al., 1996).

Another important contributory factor to Undaria's successful invasion of the south coast of England was the availability of "space". This was provided by the absence of large macroalgae on the sides of the majority of floating pontoons at the marinas. The normal, subtidal community of canopy-forming kelp algae was very poorly represented at the marinas and was generally confined to the outer, more exposed regions only. They were particularly absent from the estuarine waters associated with the Hamble marinas. This relatively unfilled niche was very quickly taken up by the Undaria plants and they became the most dominant algal component, attaining substantial biomass values. Whether such an available "space" is present in the subtidal region on natural substrata along the south coast of England remains to be seen, although observations on populations of Undaria on the north coast of Brittany indicate that major settlements are present (Castric-Fey et al., 1993).

Other contributory factors to the successful invasion by Undaria include the apparent suitability of the south coast of England for the growth and development of the plants, and the relative lack of grazers at the sites of infection. For example, plants can complete their annual reproductive cycle and life history, exhibit excellent growth rates, attaining lengths of up to $2.4 \mathrm{~m}$ (Fig. 4) and have a much more extended period of growth and development compared to native plants. Plants are present throughout the year, including fertile plants with sporophylls capable of releasing viable spores. Conditions do, therefore, seem to be optimal for the development of Undaria and appear to equal if not better those of Undaria's place of origin. Coupled with the lack of any noteworthy grazers, the environment of the floating pontoons appears most suitable for the 
invasive process. Except for during the period of senescence in late summer, the plants also appear very healthy throughout their development and show no signs of infections similar to those associated with the white rot disease described for cultivated plants in Japan (Akiyama, 1997). Probably, however, the most important factors contributing to Undaria's successful invasion are the alga's wide ranging adventive properties. These include:

- The ability to rapidly colonise new or disturbed substrata (i.e. Undaria can play a strong pioneering role)

- The ability to colonise a wide range of artificial structures, including floating structures, which not only assisted the introduction of Undaria into the south coast of England via boats but also strongly contributed to its marginal dispersal

- The ability to colonise a wide range of substrata, including a range of host plants and animals

- A fast growth rate, producing large canopy-forming sporophytes

- A large reproductive spore output, with fertile plants found throughout the year

- A wide seasonal distribution period, with plants present throughout the year

- A wide physiological tolerance with respect to temperature, light and salinity (Floc'h et al., 1991)

- A wide vertical distribution in the subtidal region (down to $18 \mathrm{~m}$ in Brittany according to Floc'h et al., 1991; Castric-Fey et al., 1993)

In combination, all these factors have contributed to the successful establishment of Undaria on the south coast of England and will undoubtedly further contribute to its continued success and expansion throughout a much wider area of the North Atlantic. Certainly it is likely to considerably extend its geographical distribution, quite probably from Norway to Mauritania as suggested by Floc'h et al. (1991). Whilst remote dispersal will most probably be rapid via the hulls of small boats, marginal dispersal by the release and dissemination of reproductive spores is likely to be a much slower process. It will be a major fouling alga in harbours and ports throughout Europe, but its likely impact on natural rocky substrata is less predictable. Work in Brittany suggests that populations of plants will occur mainly in the shallow subtidal benthos but that its competitive ability is low, and it will only pose a threat to annuals such as Saccorhiza polyschides and not be able to compete with native perennial canopy species (Floc'h et al., 1991). Observations on plant populations in the Hamble Estuary also suggest that Undaria is more tolerant of estuarine, muddy environments than native kelp species and will contribute significantly to the volume of plant biomass in these situations. As estuaries are important nursery grounds for small fish, the introduction of the Undaria into these habitats could be considered ecologically beneficial. For certain, Undaria is now a permanent addition to the flora of the North Atlantic. The full extent of its likely impact, however, remains to be determined. 


\section{LITERATURE CITED}

Akiyama, K., 1977. On the Olpidiopsis disease of juvenile Undaria pinnatifida in field culture. Bull. Toh. Reg. Fish. Res. Lab. 37, 43-49.

Akiyama, K. \& Kurogi, M., 1982. Cultivation of Undaria pinnatifida (Harvey) Suringar, the decrease of crops from the natural plants following crop increase from cultivation. - Bull. Toh. Reg. Fish. Res. Lab. 44, 91-100.

Boalch, G. T., 1981. Do we really need to grow Macrocystis in Europe? In: Proceedings Xth International Seaweed Symposium. Ed. by T. Levring, de Gruyter, Berlin. 657-667.

Boalch, G. T., 1994. The introduction of non-indigenous species to Europe: planktonic species. In: introduced species in European coastal waters. Ed, by C. F. Bondouresque, F. Briand \& $C$. Nolan. European Commission Ecosystems Research Report 8, 28-31.

Bokn, T. \& Lein, T. E., 1978. Long-term changes in association of the inner Oslofjord, Norway, Norw. J. Bot. 25, 9-14

Bolton, J. J., Germann, I. \& Luning, K., 1983. Hybridisation between Atlantic and Pacific representatives of the Simplices section of Laminaria (Phaeophyceae). - Phycologia 22, 133-140.

Boudouresque, C. F. 1994. Les espèces introduites dans les eaux côtières d'Europe et de Méditerranée: état de la question et conséquences. In: Introduced species in European coastal waters. Ed. by C. F. Boudouresque, F. Briand \& C. Nolan. European Commission Ecosystems Research Report $8,8-27$

Boudouresque, C. F. Gerbal, M. \& Knoepptler-Peguy, K., 1985. L'algue Japonaise Undaria pinnatifida (Phaeophyceae, Laminariales) en Méditerranée, - Phycologia 24, 364-366.

Brown, M. T. \& Lamare. M. D. 1994. L'algue Japonaise Undaria pinnatifida (Harvey) Suringar within Timaru Harbour. New Zealand. - Jpn. J. Phyc. 42, 63-70.

Casas, G. N. \& Piriz, M. L., 1996. Surveys of Undana pinnatiida (Laminariales, Phaeophyta) in Golfo Nuevo, Argentina. - Hydrobiologia 326/327, 213-215.

Castric-Fey, A., Girard, A. \& L'Hardy-Halos, M. T., 1993. The distribution of Undaria pinnatiiida (Phaeophyceae, Laminariales) on the coast of St. Malo (Brittany, France). - Bot. Mar. 36, 351-58.

Castric-Fey, A. \& L'Hardy-Halos, M. T., 1996. L'expansion d'Undaria pinnatifida (Laminariale, Alariacee) dans la région malouine, premières observations. In: Second international workshop on Caulerpa taxifolia. Ed. by M. A. Ribera, E. Ballesteros, C. F. Boudouresque, A. Gomez, C. Gravez Publicacions Universitat Barcelona 1996, 407-412.

Cotton, A. D., 1908. The appearance of Colpomenia sinuosa in Britain. - Bull. Misc. Inf. R. Bot. Gdns Kew, L908, 73-77.

Critchley, A. T., Farnham, W. F., Yoshida, T. \& Norton T. A., 1990. A bibliography of the invasive alga Sargassum mulicum (Yendo) Fensholt (Fucales; Sargassaceae). - Bot. Mar. 33, 6, 551-62.

Critchley, A., \& Thorp, C. H., 1985. Janua (Dexiospira) brasiliensis (Grube) (Polychaeta: Spirarhidae): a new record from the south-west Netherlands. - Zool. Bijdr. 31, 1-8.

Curiel, D., Rismondo, A. Marzocchi, M. \& Solazzi, A., 1994. Distribuzione di Undaria pinnatifida da nella laguna di Venezia. - Lav. Soc. Ven. Sc. Nat. 19, 121-126.

Eno, N. C., Clark, R. A. \& Sanderson W. G., 1997. Non-native marine species in British waters: a review and directory. - Joint Nature Conservation Committee, Peterborough pp. 152.

Farnham, W. F., 1980. Studies on aliens in the marine algal flora of southern England. In: Systematics Assoc. special vol. 17 (b), The shore environment, vol. 2: ecosystems. Ed. by J. H. Price, D. E. G. Irvine \& W. F. Farnham. Academic Press, London, 875-914.

Farnham, W. F., 1994. Introduction of marine benthic algae into Atlantic European waters. In: In troduced species in European coastal waters. Ed. by C. F. Boudouresque, F. Briand \& C. Nolan. European Commission Ecosystems Research Report 8, 32-36.

Farnham, W. F., 1997. Especes invasives sur les côtes de la Manche et de l'Atlantique. In: Dynamique d'espèces marines invasives: application à l'expansion de Caulerpa taxifolia en Méditerranée. Proc. Int. Semin. Acads. Sci. Tec. Doc, Paris, 15-33.

Farnham, W. F., Fletcher, R. L. \& Irvine, L. M. 1973. Attached Sargassum found in Britain. - Nature $243,231-232$.

Fletcher, R. L., 1974. Studies on the life history and taxonomy of some members of the Phaeophycean families Ralfsiaceae and Scytosiphonaceae. - Ph.D. Thesis, University of London 
Fletcher, R. L., 1983. The occurrence of the brown alga Streblonema oligosporum Strömfelt in Britain. - Br. Phycol. J. 18, 415-423.

Fletcher, R. L., 1987. Seaweeds of the British Isles. Vol. 3. Fucophycede (Phaeophyceae). Part 1. British Museum (Natural History) Publications, London, pp. 359.

Fletcher, R. L. \& Manfredi, C., 1995. The occurrence of Undaria pinnatifida (Phaeophyceae, Laminariales) on the south coast of England. - Bot. Mar. 38, 1-4.

Floc'h, J. Y., Pajot, R. \& Wallentinus, 1., 1988. The Japanese brown alga Undaria pinnatifida on the coasts of France and the possibilities of its establishment in European waters. - ICES publication: case historys of the effects of the transfers and introductions of marine resources, Bergen, Norway, 10 October 1988.

Floc'h, J. Y., Pajot, R. \& Wallentinus, I., 1991. The Japanese brown alga Undaria pinnatifida on the coasts of France and the possibilities of its establishment in European waters. - J. Cons. Int. Explor. Mer. 47, 379-390.

Floc'h, J. Y., Pajot, R. \& Mouret, V., 1996. Undaria pinnatifida (Laminariales, Phaeophyta) 12 years after its introduction into the Atlantic Ocean. - Hydrobiologia 326/237, 217-222.

Franklin, A., 1974. Giant kelp for Europe. - New Scientist, 12 December 1974, 812-813.

Gaetano, G. M., 1992. Sargassum muticum (Yendo) Fensholt (Phaeophyta, Fucales) is spreading in the lagoon of Venice (Northern Adriatic Sea). - Giorn. Bot. Ital. 126, 2, 259.

Giaccone, G., 1978. Revisione della flora marina del mare Adriatico. - Parco Marino Miramare, Trieste, $6,1-118$.

Hay, C. H., 1990. The dispersal of sporophytes of Undaria pinnatifida by coastal shipping in New Zealand, and implications for further dispersal of Undaria in France. - Br. Phycol. J. 25, 301313.

Hay, C. H., Luckens, P. A., 1987. The Asian kelp Undaria pinnatifida (Phaeophyta: Laminariales) tound in a New Zealand harbour. - New Zealand J. Bot. 25, 329-332.

Jephson, N. A., Fletcher, R. L. \& Berryman, J., 1975. The occurrence of Zanardinia prototypus on the south coast of England. - Br. Phycol. J. 10, 253-255.

Knight-Jones, P., Wyn Knight-Jones, E., Thorp, C. H. \& Gray, W. G., 1975. Immigrant Spirorbids (Polychaeta Sedentaria) on the Japanese Sargassum at Portsmouth, England. - Zool. Scr. 4 , 145-49.

Knoepffler-Peguy, M., Belsher, T., Boudouresque, C. F. \& Lauret, M., 1985. Sargassum muticum begins to invade the Mediterranean. - Aquat. Bot. 23, 291-295.

Parke, M., 1948. Laminaria ochroleuca de la Pylaie growing on the coast of Britain. - Nature 162, 295.

Perez, R. Kaas, R. \& Barbaroux, O., 1984. Culture experimentale de l'algue Undaria pinnatifida sur les cotes des France. - Science et Peche 343, 5-15.

Perez-Cirera, J. L., Cremades, J., Barbara, I. \& Lopez, M. C., 1991. Contribucion al conocimiento del genero Phyllariopsis (Phyllariaceae, Phaeophyta) en el Atlantico europeo. - Nova Acta Cientifica Compostelana (Bioloxia) 2, 3-11.

Ribera, M. A. \& Boudouresque, C. F., 1995. Introduced marine plants with special reference to macroalgae: mechanisms and impact. - Prog. Phycol. Res. 11, 188-268.

Ribera, M. A., Gomez Garreta, A., Gallardo, T., Cormaci, M., Furnari, G. \& Giaccone, G., 1992. Check-list of Mediterranean seaweeds I. Fucophyceae (Warming, 1884) . - Bot. Mar. 35, 2, 10930.

Riouall, R., 1985. Sur la présence dans l'Etang de Thau (Hérault-France) de Sphaerotrichia divaricata (C. Ag.) Kylin et Chorda filum (L.) Stackhouse. - Bot. Mar. 28, 83-86.

Rueness, J., 1989. Sargassum muticum and other introduced Japanese macroalgae: biological pollution of European coasts. - Mar. Poll. Bull. 20, 173-176.

Saito, Y., 1975. Undaria. In: Advances in Phycology in Japan. 4. Ed. by J. Tohida \& H. Hirose. Junk, The Hague, 304-320.

Santiago Caamano, J., Duran Neira, C. \& Acuna Castroviejo, R., 1990. Aparicion de Undaria pinnatifida en la costas de Galicia (Espana). Unnuevo casa en la problematica de introduccio de especies foraneas. - Inf. Tec. Cen. Invest. Sub S. L. (CIS) 3, 1-45. 
Schueller, G. H. \& Peters, A. F., 1994. Arrival of Fucus evanescens (Phaeophyceae) in Kiel Bight (Western Baltic). - Bot. Mar. 37, 471-477.

Thorp, C. H., Knight-Jones, P. \& Knight-Jones, E. W., 1986. New records of tubeworms established in British harbours. - J. mar. biol. Ass. U.K. 66, 881-888.

Tokida, J., 1954. The marine algae of southern Saghalien. - Mem. Fac. Fish. Hokkaido Univ. 2, 1264.

Verlaque, M., 1994. Inventaire des plantes introduites en Méditerranée: origines et répercussions sur l'environnement et les activites humaines. - Oceanol. Acta 17, 1, 1-23.

Zibrowius, H. \& Thorp, C. H., 1989. A review of alien serpulid and spirorbid polychaetes in the British Isles. - Cah. Biol. Mar. 30, 271-285. 